\title{
EVALUATION OF NEW RED WINEMAKING TECHNOLOGIES THROUGH CONSUMER LIKING
}

\author{
Avaliação de novas tecnologias de vinificação em tinto através da aceitação de consumidores
}

\author{
Maurício Bonatto Machado de Castilhos ${ }^{1}$, Ana Carolina Conti e Silva², Vanildo Luiz Del Bianchi²
}

\begin{abstract}
Several studies proposed changes in winemaking technology in order to improve wine quality, reflecting on its high acceptance. Thus, the aim of this work was to evaluate the influence of pre-drying and constant pumping effect technologies on sensory attributes of Bordô (Ives) and Isabel red wines through the acceptance evaluation of appearance, aroma, body, flavor and overall acceptance. Eighty consumers evaluated the samples using a 9-point structured scale and sensory data were analyzed by Cluster Analysis followed by Multidimensional Scaling. Significant differences $(\mathrm{P}<0.001)$ were observed in the comparison of the samples in all sensory attributes, highlighting the wide acceptance of the samples from innovative winemaking. In addition, Cluster Analysis showed the split of consumer preferences which revealed the higher preference and purchase intention of the pre-drying and static pomace wines. The correlation between flavor and overall acceptance was significant $(\mathrm{P}<0.001 ; r>0.700)$ and the consumer panel showed that the overall acceptance of the wines was influenced by the flavor, regardless of the other attributes. The higher acceptance of the pre-drying and static pomace wines suggests the potential of these winemaking processes.
\end{abstract}

Index terms: American grapes, winemaking, drying, static pomace, consumer acceptance.

\section{RESUMO}

Existem diversos estudos que propõem mudanças na tecnologia de vinificação para melhorar a qualidade do vinho tinto, refletindo na sua maior aceitabilidade. Nesse contexto, o objetivo do presente artigo foi avaliar a influência da pré-secagem e da remontagem constante na aceitabilidade dos vinhos tintos das cultivares Bordô (Ives) e Isabel quanto aos atributos aparência, aroma, corpo, sabor e à impressão global (aceitação global). Oitenta consumidores avaliaram as amostras utilizando uma escala hedônica estruturada de 9 pontos e uma escala de intenção de compra de 5 pontos. Os dados hedônicos foram analisados por meio da Análise de Cluster e Escalonamento Multidimensional. Diferenças significativas $(\mathrm{P}<0.001)$ foram observadas na comparação das amostras em todos os atributos sensoriais, destacando a grande aceitação das amostras elaboradas pelas técnicas inovadoras. Adicionalmente, a Análise de Cluster mostrou com sucesso a segmentação da preferência dos consumidores, mostrando a relevante aceitação dos vinhos dos tratamentos de pré-secagem e bagaço estático. A correlação entre o sabor e a aceitação global foi significativa $(\mathrm{P}<0.001 ; \mathrm{r}>0.700)$, mostrando que o sabor exerce grande influência na avaliação global das amostras de vinho, independentemente dos outros atributos. A relevante aceitação global dos vinhos dos tratamentos inovadores sugere o grande potencial desses processos de vinificação.

Termos para indexação: Uvas americanas, vinificação, secagem, bagaço estático, aceitação de consumidores.

(Received in october 23, 2012 and approved in february 8, 2013)

\section{INTRODUCTION}

Red wine and its derivatives are produced in Brazil with American cultivars and hybrid grapes from Vitis labrusca species, which are responsible for more than $85 \%$ of the volume of grape production in Brazil (NIXDORF; HERMOSÍN-GUTIÉRREZ, 2010). Scientific studies have shown that the habit of daily intake of red wine may be correlated to longevity, due to the presence of resveratrol that prevents the occurrence of cardiovascular diseases such as arteriosclerosis and thrombosis, controlling diabetes and reducing the risks of some cancers (GOLDFINGER, 2003). For these and other reasons, red wines from American cultivars are widely studied worldwide, especially regarding to sensory acceptance by consumers (CASTILHOS et al., 2012).

Wine is a complex beverage with many characteristics which can affect consumer preference. Appearance, aroma, flavor, body and aftertaste contribute to the overall quality and acceptance of a wine (DOOLEY et al., 2012). Evaluation of wine quality is usually committed to wine experts, however, there are no evidences that these experts can predict consumer preferences, because segmentation on consumer preferences exists and leads to different approaches in wine assessment studies (KING et al., 2010; KING et al., 2011).

Human perception of wine attributes can be measured using traditional sensory evaluation practices

1Universidade Estadual Paulista “Júlio de Mesquita Filho"/UNESP - 15054-000 - São José do Rio Preto - SP - Brasil - mbonattosp@yahoo.com.br 2Universidade Estadual Paulista "Júlio de Mesquita Filho"/UNESP - Departamento de Engenharia e Tecnologia de Alimentos - São José do Rio Preto $\mathrm{SP}-$ Brasil

Ciênc. agrotec., Lavras, v. 37, n. 2, p. 170-178, mar./abr., 2013 
aiming to detect differences between wine samples, quantify sensory attributes by the application of descriptive assessment and test the preference or liking of wines by consumers (STONE; SIDEL, 2004). Other factors apart sensory analysis can influence the consumer preference behavior such as brand, pricing, packaging and promotion. However, these extrinsic factors do not influence the consumer acceptance in blind assessments, allowing a direct measure of the response (KING et al., 2010).

There have been some researches concerning the variations in winemaking processes which lead to changes in sensory attributes and consumer preferences (CHIRA et al., 2011; GREEN et al., 2011; CASTILHOS et al., 2012) and most of these studies evaluated consumer preference by the application of multivariate statistical tools such as Principal Component Analysis and Cluster Analysis followed by Multidimensional Scaling. This statistical approach is taking its rightful place in the analysis of sensory results, because provide interesting findings that are not found in the univariate approach.

This work aimed to evaluate the influence of two innovative processes of vinification: pre-drying and static pomace on consumer liking of Bordô (Ives) and Isabel wines, comparing them to a traditional winemaking.

\section{MATERIAL AND METHODS}

\section{Grapes}

The grapes used in this study were two different Vitis labrusca species: Isabel and Bordô (Ives). These grapes are known by their rusticity since they present high resistance to major diseases of the vines such as anthracnose, mildews and some types of decay. Furthermore, they also have some versatility in relation to the crop planning, eliminating off-season periods which promote high profitability of the season (GIOVANINNI, 2001). Bordô and Isabel grapes present a foxy and fruity flavor linked to red fruits and raspberry, respectively. Isabel are responsible for $40 \%$ of the total production of the grapes in Brazil and they are led to the production of sweet wine, vinegar, jams and fresh consumption (RIZZON et al., 2000). Bordô grape presents high coloring strength and this feature is responsible for its large application in "assemblage" wines in order to make them full-bodied to the taste (RIZZON et al., 1994).

The grapes used in this study were harvested in Jales, a small town located in Northwest region of São Paulo State, Brazil.

\section{Wine samples}

The samples of red wine were produced using a standard procedure of winemaking using 10-L flasks equipped with hydraulic stopper that enabled the output of carbon dioxide, product of the alcoholic fermentation, and prevented the entrance of the oxygen into the flask. The grapes were manually destemmed and crushed allowing the contact between juice and pomace, promoting the beginning of alcoholic fermentation that lasted 7 days. Before proceeding to the dejuicing, an aliquot of the must was collected to calculate the density according to equation 1 (BOULTON et al., 1996).

${ }^{\circ}$ Brix $=261.6-(261.6 /$ Must density $)$

The ideal point of dejuicing was determined by the must density after alcoholic fermentation. After dejuicing, wines from traditional and static pomace treatments were submitted to sugaring in order to adjust the alcohol content to $11^{\circ} \mathrm{GL}$, knowing that $18 \mathrm{~g} \mathrm{~L}^{-1}$ of sugar $\left(1.8^{\circ} \mathrm{Babo}\right)$ generate $1{ }^{\circ} \mathrm{GL}$ of ethanol (JACKSON, 2008). After the chaptalization step, it was performed three racking with ten days between them, followed by 90 days of stabilization. Wines from static pomace treatment followed the winemaking standard procedure with "constant pumping effect", and it was possible to be performed due to the use of stainless steel screens which kept the pomace static and in permanent contact with the juice.

The pre-drying treatment aimed at drying the grapes to a point where soluble solids content reaches $22^{\circ} \mathrm{Brix}$, yielding wines with an alcohol content between 8.6 to 14 ${ }^{\circ} \mathrm{GL}$, according to Brazilian legislation, avoiding the sugaring process. For drying process it was used the convective tray drier with a temperature of $60^{\circ} \mathrm{C}$ and air flow $1.1 \mathrm{~m} \mathrm{~s}^{-1}$ (DOYMAZ, 2006). Being $U$ the moisture of the grapes determined by vacuum oven on a wet basis $\left(60^{\circ}\right.$ C for 24 hours); B the soluble solids content of the sample ( ${ }^{\circ}$ Brix) determined by refractometry; $m_{\text {grape }}$ the mass of grapes in grams; $\mathrm{m}_{\text {water }}$ the mass of water moisture from the representative sample; $m_{\text {dry }}$ the mass of dry material of the sample; $\mathrm{m}_{\text {sugar }}$ the mass of sugar and $\mathrm{m}_{\text {others }}$ the mass of others substances in the sample, it was possible to determinate the following relations (Equations 02 to 05 ):

$$
\mathrm{m}_{\text {water }}=\mathrm{m}_{\text {grape }} \cdot \mathrm{U}
$$

$$
\mathrm{m}_{\text {dry }}=(1-\mathrm{U}) \cdot \mathrm{m}_{\text {grape }}
$$


$\mathrm{m}_{\text {sugar }}=\mathrm{m}_{\text {water }} \cdot \mathrm{B}$

$\mathrm{m}_{\text {others }}=\mathrm{m}_{\mathrm{dry}}-\mathrm{m}_{\text {sugar }}$

In order to determine the amount of water evaporated for the grapes to reach $22^{\circ}$ Brix $(B=0.22 \mathrm{~g}$ of soluble solids per gram of grape) at the end of the drying process, and knowing that $\mathrm{m}_{\text {dry }}, \mathrm{m}_{\text {others }}$ and $\mathrm{m}_{\text {sugar }}$ did not change during the drying process, it was possible to determine the final stage of drying through the following relations (Equations 06 to 08):

$\mathrm{m}_{\text {water }}=\mathrm{m}_{\text {sugar }} / \mathrm{B}$

$\mathrm{U}=\mathrm{m}_{\mathrm{water}} /\left(\mathrm{m}_{\mathrm{dry}}+\mathrm{m}_{\mathrm{water}}\right)$

$\mathrm{m}_{\text {grape }}=\mathrm{m}_{\text {water }} / \mathrm{U}$

After the drying, the grapes were submitted to the standard winemaking process described above with the exception of the chaptalization step. Density $\left(\mathrm{g} . \mathrm{cm}^{-3}\right)$ and alcohol content $\left({ }^{\circ} \mathrm{GL}\right)$ were determined by gravimetry using pycnometer coupled with thermometer and analytical balance (ASSOCIATION OF OFFICIALANALYTICAL CHEMISTS-AOAC, 2005) and phenolic compounds were determined using absorbance spectrophotometer Quimis Q798U at $765 \mathrm{~nm}$, as describe by Singleton and Rossi (1965).

\section{Sensory evaluation}

The sensory study was carried out in the Sensory Analysis Laboratory of the São Paulo State University by 80 consumers (students, staff and professors of São Paulo State University) who analyzed the preference of eight wines, six samples related to treatments (TB: Traditional Bordô wine, TI: Traditional Isabel wine, PDB: Pre-drying Bordô wine, PDI: Pre-drying Isabel wine, SPB: Static pomace Bordô wine, SPI: Static pomace Isabel wine) and two commercial red wines (CB: Bordô varietal wine, CI: Bordô and Isabel assemblage wine), both from Serra Gaúcha, Southern Brazil.

Consumers used a structured 9 -point scale $(9=$ like extremely, 5 = neither like nor dislike, 1 = dislike extremely) to evaluate attributes of appearance, aroma, body, flavor and overall acceptance. The purchase intent using a 5point scale ( 1 = definitely would not buy, 5 = definitely would buy) was also evaluated. Consumers were directed towards individual booths with a uniform white light source and controlled ambient temperature $\left(24 \pm 1^{\circ} \mathrm{C}\right)$. Wines were served in $30 \mathrm{~mL}$ glass cups with approximately $15 \mathrm{~mL}$ of sample at $25^{\circ} \mathrm{C}$ with a glass of water for mouth rinsing.
The sensory tests were carried out on three days. The experimental design used was incomplete block (MEILGAARD et al., 1999) and each consumer evaluated five from the eight samples. The samples were presented in a monadic and randomized order, coded with three-digit random numbers. The ethical issues of the sensory analysis were approved by the Research Ethics Committee of the Instituto de Biociências, Letras e Ciências Exatas, São Paulo State University (protocol n. 0019.0.229.000-10).

\section{Data analysis}

The consumer liking data were analyzed by Oneway Analysis of Variance (ANOVA) and when significant differences were detected Tukey test was applied to compare means differences of the attributes among wine samples. The scores from sensory analysis were also analyzed by Cluster Analysis followed by Multidimensional Scaling and Pearson correlation, considering a coefficient greater than 0.700 as significant correlation. All statistical tests were carried out using 0.05 of significance level and all data were analyzed by Statistica by Statsoft ${ }^{\circledR}$ (STATISTICA, 2004).

\section{RESULTS AND DISCUSSION}

\section{Wine characterization}

The density of Bordô and Isabel musts ranged from 1.079 to $1.093 \mathrm{~g} \mathrm{~cm}^{-3}$ and 1.078 to $1.092 \mathrm{~g} \mathrm{~cm}^{-3}$, respectively, and the total phenolic compounds ranged from 1232.7 to $1303.8 \mathrm{mg} \mathrm{L}^{-1}$ and 506.6 to $1038.8 \mathrm{mg} \mathrm{L}^{-1}$, respectively. The highest values were linked to pre-drying treatment regardless of the grape. This result was expected, because the removal of water from drying process increased the soluble solids and the phenolic compounds responsible for the color strength of these wines (AMERINE; OUGH, 1988). Alcohol content was determined and samples PDI and SPI showed higher alcohol content $\left(12.53^{\circ} \mathrm{GL}\right.$ and $11.76^{\circ} \mathrm{GL}$, respectively) whereas samples SPB and TI showed lower alcohol content $\left(10.46^{\circ} \mathrm{GL}\right.$ and $9.76^{\circ} \mathrm{GL}$, respectively).

\section{Sensory evaluation}

The average age of the panelists was 24 years old with a standard deviation of 8 years and minimum of 18 years and a maximum of 57 years. Among 80 consumers, $43(53.75 \%)$ were female, $66(82.50 \%)$ presented age between 18 and 25 years and $63(78.75 \%)$ were undergraduate students. From this total, 47 consumers $(58.75 \%)$ use to drink at least two glasses of wine or more per month (Table 1). 
In all sensory attributes, the results showed that the six samples regarding to the traditional and innovative treatments had greater acceptance when compared to the two commercial samples (Table 2). Initially, all sensory attributes were analyzed by multivariate approach. Results showed two distinct clusters: one cluster with all studied treatments (traditional, pre-drying and static pomace wines) and another cluster with the commercial wines. This result did not allow to determinate which studied treatment or which group of studied samples presented higher acceptance because they were allocated in the same cluster. In order to observe the split of consumer liking and to know which of the studied samples presented higher acceptance, the commercial wines were excluded from multivariate analysis. Other multivariate analyses were performed. Cluster Analysis is represented in figure 1 and Multidimensional Scaling results are shown in figure 2, where consumers are numbered according to the cluster they belong to.

Table 1 - Consumers' characterization and frequency of consumption of red wines.

\begin{tabular}{lr}
\hline Gender & Count (Frequency) \\
Female & $43(53.75 \%)$ \\
Male & $37(46.25 \%)$ \\
Age & \\
$18-25$ & $66(82.50 \%)$ \\
$26-35$ & $8(10.00 \%)$ \\
$36-60$ & $6(7.50 \%)$ \\
Professional activity & $63(78.75 \%)$ \\
Undergraduate student & $10(12.50 \%)$ \\
Postgraduate student & $5(6.25 \%)$ \\
Professor & $2(2.50 \%)$ \\
Employee & $6(7.50 \%)$ \\
Consumption frequency of red wines & $18(22.50 \%)$ \\
Considerable (more than 4 glasses per month) & $23(28.75 \%)$ \\
Moderate (up to 4 glasses per month) & $10(12.50 \%)$ \\
Occasionally (2 glasses per month) & $23(28.75 \%)$ \\
Slightly (1 glass per month) & \\
Very slightly (less than 1 glass per month) & \\
\hline
\end{tabular}

Table 2 - Results (Mean \pm Standard deviation) of the sensory attributes.

\begin{tabular}{clllll}
\hline \multirow{2}{*}{ Wines $^{*}$} & \multicolumn{5}{c}{ Attributes } \\
\cline { 2 - 6 } & Appearance & \multicolumn{1}{c}{ Aroma } & \multicolumn{1}{c}{ Body } & \multicolumn{1}{c}{ Flavor } & Overall acceptance \\
\hline TB & $7.60^{\mathrm{a}} \pm 1.19$ & $6.22^{\mathrm{abc}} \pm 1.70$ & $6.28^{\mathrm{a}} \pm 1.56$ & $4.72^{\mathrm{ab}} \pm 2.03$ & $5.68^{\mathrm{ab}} \pm 1.77$ \\
TI & $6.50^{\mathrm{bc}} \pm 1.16$ & $6.18^{\mathrm{abc}} \pm 1.88$ & $5.52^{\mathrm{abc}} \pm 1.77$ & $4.80^{\mathrm{ab}} \pm 2.15$ & $5.32^{\mathrm{abc}} \pm 1.86$ \\
PDB & $7.48^{\mathrm{a}} \pm 1.37$ & $6.62^{\mathrm{a}} \pm 1.51$ & $6.54^{\mathrm{a}} \pm 1.78$ & $5.28^{\mathrm{a}} \pm 2.05$ & $5.98^{\mathrm{a}} \pm 1.75$ \\
PDI & $7.10^{\mathrm{ab}} \pm 1.37$ & $6.30^{\mathrm{ab}} \pm 1.21$ & $5.92^{\mathrm{abc}} \pm 1.65$ & $4.88^{\mathrm{ab}} \pm 1.81$ & $5.60^{\mathrm{abc}} \pm 1.51$ \\
SPB & $6.90^{\mathrm{ab}} \pm 1.66$ & $6.00^{\mathrm{abc}} \pm 1.71$ & $5.86^{\mathrm{abc}} \pm 1.69$ & $4.94^{\mathrm{ab}} \pm 2.20$ & $5.54^{\mathrm{abc} \pm 1.73}$ \\
SPI & $6.98^{\mathrm{ab}} \pm 1.20$ & $6.40^{\mathrm{ab}} \pm 1.64$ & $6.06^{\mathrm{ab}} \pm 1.54$ & $5.40^{\mathrm{a}} \pm 1.94$ & $6.06^{\mathrm{a}} \pm 1.61$ \\
CB & $5.60^{\mathrm{cd}} \pm 2.15$ & $5.26^{\mathrm{c}} \pm 2.05$ & $5.18^{\mathrm{bc}} \pm 1.71$ & $4.00^{\mathrm{b}} \pm 2.19$ & $4.66^{\mathrm{bc}} \pm 1.89$ \\
CI & $5.32^{\mathrm{d}} \pm 1.77$ & $5.46^{\mathrm{bc}} \pm 1.83$ & $4.98^{\mathrm{c}} \pm 1.84$ & $3.90^{\mathrm{b}} \pm 1.91$ & $4.56^{\mathrm{c}} \pm 1.75$ \\
\hline
\end{tabular}

"Means followed by different letters in the same column differ by Tukey test at 0.001 of significance. 

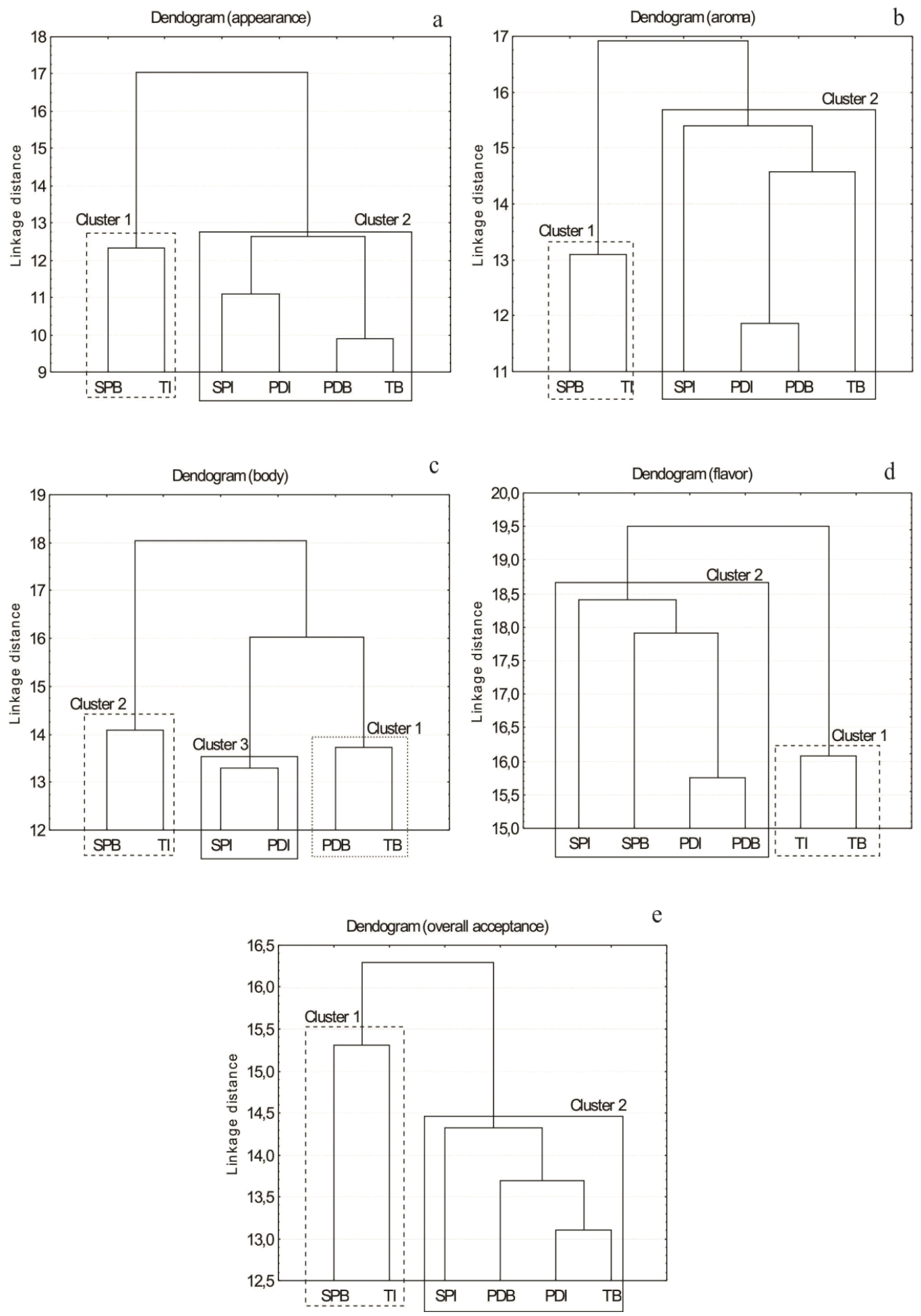

Figure 1 - Cluster analysis of the red wines and consumers $(\mathrm{n}=80)$ for appearance $(\mathrm{a})$, aroma (b), body (c), flavor $(\mathrm{d})$ and overall acceptance (e). TB: Traditional Bordô wine, TI: Traditional Isabel wine, PDB: Pre-Drying Bordô wine, PDI: Pre-Drying Isabel wine, SPB: Static Pomace Bordô wine, SPI: Static Pomace Isabel wine. 

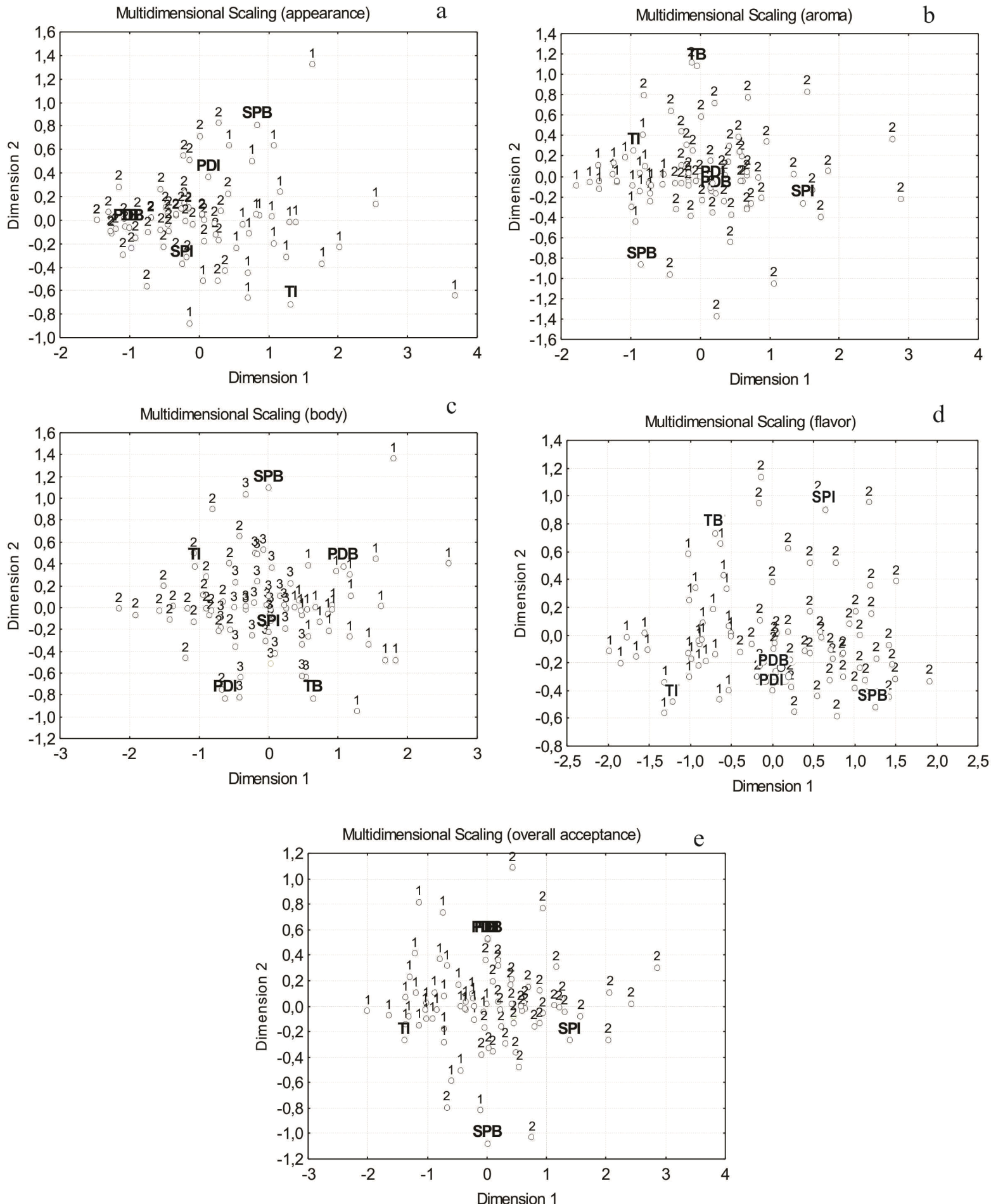

Figure 2-Multidimensional scaling of the red wines and consumers $(n=80)$ for appearance (a), aroma (b), body (c), flavor (d) and overall acceptance (e). TB: Traditional Bordô wine, TI: Traditional Isabel wine, PDB: Pre-Drying Bordô wine, PDI: Pre-Drying Isabel wine, SPB: Static Pomace Bordô wine, SPI: Static Pomace Isabel wine. 
Restricting the wine samples in traditional and innovative treatments only, it was possible to observe the emphasis on acceptance of the PDB and SPI samples, which demonstrated the wide acceptance of innovative treatments compared to the traditional winemaking.

For appearance, it was possible to observe two clusters: cluster 1 composed by SPB and TI samples with 23 consumers and cluster 2 composed by TB, PDB, PDI and SPI samples with 57 consumers. It was noticed that the wines of the pre-drying process were highlighted in the evaluation of appearance, considered as the most acceptable for this attribute. It is assumed that this result is linked to the concentration of phenolic compounds due to pre-drying process which allowed more visual attraction for these samples by the consumers (SAPERS et al., 1981). The sample SPI also showed a large acceptance for this attribute, due to the greater extraction of phenolic compounds, especially anthocyanins, which produce wines with greater color strength, contradicting the literature which shows that pumping effect improve the phenolic extraction and enhance the red wine color (RIBÉREAU-GAYON et al., 2000).

Aroma results showed the split of the consumer acceptance into two clusters: cluster 1 composed bySPB and TI samples with 23 consumers and cluster 2 composed by SPI, PDB, PDI and TB samples with 57 consumers. Wines submitted to pre-drying process revealed greater aroma acceptance, which is important to be discussed, because it is assumed that drying produce aromatic wines.

The temperature influences directly on the aromatic composition of wines, because the concentration of fruity compounds (thiols) increases as the temperature of the winemaking increases. This presupposes that, regardless of the yeast used in fermentation, the production of aromatic compounds is enhanced at higher temperatures (CHEYNIER et al., 2010), explaining in a way, the higher acceptance of the aroma attribute for the samples submitted to pre-drying process. The sample SPI also showed great aroma acceptance, assuming that the constant contact between must and pomace may have contributed to the released of volatile compounds for Isabel grapes.

It was possible to verify certain balance in the number of consumers in each cluster regarding body attribute results. Samples PDB and TB composed the cluster 1 with 25 consumers, SPB and TI samples composed cluster 2 with 20 consumers and SPI and PDI samples composed cluster 3 with 33 consumers. The considerable body acceptance for the samples SPI and PDI may be linked to the effect of the high alcohol content in these samples (YANNIOTIS et al., 2007). Ribéreau-Gayon et al. (2000) described that pumping effect can enhance the ethanol production by the Saccharomyces cerevisiae yeasts during maceration. The results presuppose that the "constant pumping effect" regarding static pomace treatment may be responsible for the higher alcohol content in these samples which influenced the higher scores for the body acceptance. Furthermore, the lower body acceptance of SPB and TI samples was confirmed by the lower alcohol content presented in these wines. The differences in Bordô and Isabel wines' alcoholic strength influenced the sensory acceptance of the static pomace winemaking, showing that SPI wine had higher acceptance than SPB wine. This fact is due to the influence of the winemaking process, the climatic conditions and the cultivar itself (RIZZON; MIELE, 2006).

Flavor acceptance results yielded two clusters: cluster 1 composed by traditional treatment samples with 30 consumers and cluster 2 composed by innovative treatment samples (pre-drying and static pomace) with 50 consumers The innovative winemaking promoted greater flavor acceptance, regardless of cultivar, showing that $62.50 \%$ of the consumers preferred the wines from these treatments, featuring an important result of this research.

Overall acceptance were split into two clusters: cluster 1 was composed by SPI, PDB, PDI and TB samples with 42 consumers and cluster 2 was composed by SPB and TI samples with 38 consumers. The highest overall acceptance was correlated to the wines allocated in cluster 1 which, by the way, showed the potential of the drying treatment to produce very positive effects in the evaluated attributes to both cultivars. In addition, the static pomace Isabel wine (SPI) stood out in almost all attributes, considered a wine well accepted by consumers. In contrast, static pomace treatment of Bordô wines did not produce positive effects, highlighting the pre-drying process that showed greater acceptance for evaluated attributes.

Correlation analysis among sensory acceptance was done only with the traditional and innovative treatments. It was possible to observe significant correlations $(r>0.700$ and $\mathrm{P}<0.001)$ between flavor and overall acceptance in all samples: TB ( $\mathrm{r}=0.845)$, PDB $(\mathrm{r}=0.920), \mathrm{SPB}(\mathrm{r}=0.827), \mathrm{TI}(\mathrm{r}=0.882), \mathrm{PDI}(\mathrm{r}=0.860)$ and SPI $(\mathrm{r}=0.871)$. Overall acceptance proved fully interconnected to the flavor attribute, regardless of the cultivars and the treatments. This fact revealed that consumers connect the overall acceptance to the flavor attribute and not to the others. Additionally, body and overall acceptance $(\mathrm{r}=0.738)$ were significant correlated $(\mathrm{P}<0.001)$ for the PDB sample. The pre-drying of the grapes may have influenced the body enhancement which accounted on the overall acceptance of this sample. 
Purchase intention revealed that commercial wines presented higher rejection (probably would not buy and definitely would not buy) by the consumers, $70 \%$ for CB and $68 \%$ for CI. The samples that showed major acceptance (probably would buy and definitely would buy) were SPI (30\%) and pre-drying samples PDB (30\%) and PDI (28\%). The purchase intention frequency showed that samples from innovative winemaking presented higher acceptance as compared to commercial samples, highlighting PDB and SPI samples.

\section{CONCLUSIONS}

The study provides evidences of new trends in red winemaking technologies, showing the great potential of pre-drying and static pomace treatments compared to the traditional winemaking. Cluster analysis revealed the segmentation of consumer preferences which allowed observing greater acceptance in all attributes for the innovative treatments, especially for the PDB, PDI and SPI samples. Heating applied in pre-drying process affected the aroma acceptance and the alcohol content affected the body acceptance. PDB, PDI and SPI wines presented higher purchase intention which confirmed the results from sensory acceptance.

\section{ACKNOWLEDGMENTS}

The authors acknowledge Coordination of Improvement of Higher Education (CAPES) for financial support.

\section{REFERENCES}

AMERINE, M.A.; OUGH, C.S. Wine and must analysis. New York: John Wiley \& Sons, 1988. 377p.

\section{ASSOCIATION OF OFFICIALANALYTICAL} CHEMISTS - AOAC. Method 920.57: distillationhydrometric method for the determination of ethanol contents in red wines, 2005. 1 p.

BOULTON, R.B. et al. Principles and practices of winemaking. New York: Chapman \& Hall, 1996. $604 p$.

CASTILHOS, M.B.M.; CONTI-SILVA, A.C.; DEL BIANCHI, V.L. Effect of grape pre-drying and static pomace contact on physicochemical properties and sensory acceptance of Brazilian (Bordô and Isabel) red wines. European Food Research and Technology, Berlin, v.235, n.2, p.345-354, 2012.
CHEYNIER, V. et al. Chemistry of wine. In: MANDER, L.; LIU, H.B. (Eds.). Comprehensive Natural Products II: Chemistry and Biology. United Kingdom: Elsevier, 2010. p.1119-1182

CHIRA, K.et al. Chemical and sensory evaluation of Bordeaux wines (Cabernet Sauvignon and Merlot) and correlation with wine age. Food Chemistry, Oxford, v.126, p.1971-1977, 2011.

DOOLEY, L.; THRELFALL, R.T.; MEULLENET, J. Optimization of blended wine quality through maximization of consumer liking. Food Quality and Preference, Oxford, v.24, p.40-47, 2012.

DOYMAZ, I. Drying kinetics of black grapes treated with different solutions. Journal of Food Engineering, Oxford, v.76, p.212-217, 2006.

GOLDFINGER, T.M. Beyond the French paradox: the impact of moderate beverage alcohol and wine consumption in the prevention of cardiovascular disease. Cardiology Clinics, Philadelphia, v.21, p.449457, 2003.

GIOVANINNI, E. Uva agroecológica. PortoAlegre: Renascença, 1 ed., 2001, 125p.

GREEN, J.A. et al. Sensory and chemical characterization of Sauvignon Blanc wine: Influence of source of origin. Food Research International, Amsterdam, v.44, p. 27882797, 2011.

JACKSON, R.S. Wine science: principles and applications. New York: Academic Press, 2008. 717p.

KING, E.S. et al. The effect of multiple yeasts coinoculations on Sauvignon Blanc wine aroma composition, sensory properties and consumer preference. Food Chemistry, Oxford, v.122, p.618-626, 2010.

KING E.S.; JOHNSON, T.E.; BASTIAN, S.E.P. Consumer liking of white wines: segmentation using self-reported wine liking and wine knowledge. International Journal of Wine Business Research, Bradford, v.24, n.1, p.33-46, 2011.

MEILGAARD, M.; CIVILLE, GV.; CARR, B.T.Sensory evaluation techniques. Boca Raton: CRC Press, 1999. 464p. 
NIXDORF, S.L.; HERMOSÍN-GUTIÉRREZ, I. Brazilian red wines made from the hybrid grape cultivar Isabel: Phenolic composition and antioxidant capacity. Analytica Chimica Acta, Amsterdam, v.659, p.208-215, 2010.

RIBÉREAU-GAYON, P. et al. Handbook of enology: The chemistry of wine stabilization and treatments. New York: John Wiley \& Sons, 2000. 450p.

RIZZON, L. A.; ZANUZ, M. C.; MANFREDINI, S. Como elaborar vinho de qualidade na pequena propriedade. Bento Gonçalves: EMBRAPA Uva e Vinho, 1994. 36 p.

RIZZON, L.A.; MIELE, A. Efeito da safra vitícola na composição da uva, do mosto e do vinho Isabel da serra gaúcha, Brasil. Ciência Rural, v.36, n.3, p.959964, 2006.

RIZZON, L.A.; MIELE, A.; MENEGUZZO, J. Avaliação da uva cv. Isabel para a elaboração de vinho tinto.
Ciência e Tecnologia de Alimentos, Campinas, v.20, n.1, p.115-121, 2000.

SAPERS, G.M.; TAFFER, I.; ROSS, L.R. Functional properties of a food colorant prepared from red cabbage. Journal of Food Science, Malden, v.46, p.105-109, 1981.

SINGLETON, V. L.; ROSSI, J. A. Colorimetry of total phenolics with phosphomolybdic-phosphotungstic acid reagents. American Journal of Enology and Viticulture, Davis, v. 16, p. 144-158, 1965.

STATISTICA (2004). Data analysis software system, version 7.0.61.0. Tulsa: Stat Soft Inc.

STONE, H.; SIDEL, J.L. Sensory evaluation practices. California: Elsevier Academic Press, 2004. 408p.

YANNIOTIS, S. et al. Effect of ethanol, dry extract and glycerol on the viscosity of wine. Journal of Food Engineering, Oxford, v.81, p.399-403, 2007. 